\title{
Traditional forms of power
}

\section{TANTALIZING SHREDS OF EVIDENCE}

It has so far been shown how external forces influenced the course of events on Timor until circa 1640, and how Timor can be situated in a regional and even global context. Before proceeding with an analysis of how Europeans established direct power in the 1640s and 1650s, it will be necessary to take a closer look at the type of society that was found on the island. What were the 'traditional' political hierarchies like? How was power executed before the onset of a direct European influence? In spite of all the travel accounts and colonial and missionary reports, the seventeenth- and eighteenth-century source material for this region is not rich in ethnographic detail. The aim of the writers was to discuss matters related to the execution of colonial policy and trade, not to provide information about local culture. Occasionally, there are fragments about how the indigenous society functioned, but in order to progress we have to compare these shreds of evidence with later source material. Academically grounded ethnographies only developed in the nineteenth century, but we do possess a certain body of writing from the last 200 years carried out by Western and, later, indigenous observers. Nevertheless, such a comparison must be applied with caution. Society during the last two centuries was not identical to that of the early colonial period, and may have been substantially different in a number of respects. Although Timorese society was low-technology and apparently slow-changing until recently, the changing power relations, the dissemination of firearms, the introduction of new crops, and so on, all had an impact - whether direct or indirect - on the structure of society. 


\section{CHIEFS OR KINGS?}

In the Dutch and Portuguese sources of the seventeenth and early eighteenth centuries, there was never any question over the status of Timor's local leaders. They were kings (reis, koningen) who reigned over kingdoms (reinos, rijken). Smaller hereditary rulers like those of Rote and Sawu, who were basically lords of a few villages, were often referred to as regents (regenten) but even they were sometimes endowed with regal titles. All of this must be seen in context: the early Western seafarers were quick to categorize local American, African and Asian leaders in royal terms. Japanese daimyo, Thai chao and Burmese myowun were 'kings' to the early chroniclers of overseas expansion. In the case of Southeast Asia, the foreign visitors may have followed the Malay use of the term raja, which has a much wider usage than to simply denote autonomous monarchs. In the late eighteenth century and beyond, the status of these local monarchs shrank in colonial eyes, at a time when evolutionist and Eurocentric ideas began to make an impression on the Western mind. At the same time, the increasing technological disparity seemed to render local polities increasingly irrelevant. The indigenous leaders of the Timor area became known under lesser titles such as ruling princes (vorsten), minor princes (regulos) or quite simply rajas, something that is paralleled by the structure of the source material. The voluminous VOC records highlight a degree of interest in the affairs of local Timorese domains (or 'princedoms', as I will also call them) up until the late eighteenth century, at which point the material becomes sparser. After the fall of the Company, which took place between the early 1800 s and the 1830 s, very little information on indigenous local history is included in the official Timor records, which presents an insurmountable problem for the historian. ${ }^{1}$

Who, then, were the persons known as 'kings' to the Dutch and Portuguese? It is obvious from a brief glance at the records that their capabilities greatly differed from the abilities displayed by those who ruled the realms of Java, South Sulawesi and parts of Sumatra, which could be just as large as European kingdoms. The sheer number of domains on Timor was stunning, not to say confusing. A Portuguese report drawn up after 1769 mentions two major provinces: Servião and Belu (Provincia dos Bellos), situated in the west and the central and east of Timor, respec-

This conclusion is based on a survey of nineteenth-century records on Timor (ANRI Timor, K.43, various years) in the Arsip Nasional Republik Indonesia, Jakarta. 
tively. Servião encompassed eleven reinos while there were no less than 43 in Belu. ${ }^{2}$ Moreover, the exact names and numbers of the domains differ greatly from source to source, ${ }^{3}$ giving the impression of a complex of small and steadily shifting centres of power that become increasingly fragmentary the further east one goes. In 1867, the ex-governor Affonso de Castro calculated that the population of the Portuguese half of the island alone approximated 100,000 people, meaning there were a total of a few hundred thousand souls on the whole of Timor (Castro 1867:310). On average, therefore, a domain would have a population of perhaps 3,000 to 4,000 people, although there were significant differences in size between those domains in the east and the west. ${ }^{4}$ Looking at it from that point of view, 'chiefs' would seem a better designation than 'kings'.

Nevertheless, the Timorese domains should not be judged solely on their size, as their functionality was not necessarily in proportion to their territory or population numbers. Their variation in structure and leadership has been sufficiently elucidated by anthropologists such as B.A.G. Vroklage (1953), H.G. Schulte Nordholt (1971), Elizabeth Traube (1986), A.D.M. Parera (1994), Andrew McWilliam (2002), Sofi Ospina and Tanja Hohe (2002), and Tom Therik (2004). All of these studies, it must be emphasized, mainly draw upon twentieth-century materials. The most ambitious attempt to uncover historical layers from an analysis of late colonial data was carried out by H.G. Schulte Nordholt. Using methods drawn from structural anthropology to support his argument, he has pinpointed the structural principles embedded within the traditional princedoms of West Timor.

One important finding of his investigation was the extent to which the ruler was tied to a ritual system of precedence and power relationships that descended to a local level: 'The horizons of the world in which the Atoni live and within which formerly nearly all social relations were confined, excepting some trade relations via the coast or via itinerant Chinese traders, were restricted to the princedom' (H.G. Schulte

\footnotetext{
$2 \quad$ Faria de Morais 1934, Appendix:26. Note that Belu can also denote the Tetun-speaking area of Central Timor, the Belu language being equivalent to Tetun. Today, Belu is a kabupaten (regency) in Indonesian Timor.

Compare the lists in Freycinet (1825) and the Sarzedas document of 1811, cited in Castro 1867:202-3.

The Dutch commissioner Emanuel Francis drew up a report in 1832 in which he estimated the number of able-bodied men in the various Timorese domains; he multiplied this number by four to reach the total population size. Francis thus calculated that there were circa 439,000 people on the island, about twice De Castro's estimate; see Francis 1832, H 548, KITLV. It is difficult to assess the reliability of Francis's estimates, but the two sources suggest an overall population of well below half a million.
} 
Nordholt 1971:186). The ruler was a necessary central component of the system, but his executive powers were not usually extensive. His main task was an inactive one: to eat, drink and sleep in his abode, in the centre of the realm. The domains studied by H.G. Schulte Nordholt usually had a dual structure based on a common Timorese perception of opposition between the 'male' (mone) and the 'female' (feto) element. The inactive, resting lord of the realm would be female - notwithstanding his or her actual sex - while an active, executive regent would be male. The male-female opposition, moreover, was highly situational: a component of society could be male in one respect and female in another. Furthermore, the territory or manpower of the realm was often subjected to a pattern of bipartition or quadripartition, with one aristocratic lord or regent (usif in Dawan) leading each division. The use of spatial terminology is important in envisioning this socio-political model.

In H.G. Schulte Nordholt's scheme (1971:403), power was shored up fourfold within the princedoms: it was a political system that rested on ritual relationships expressed in rites and myths; it was consolidated by a network of kinship and marriage relations, which could help a ruling lineage expand its sphere of power; ${ }^{5}$ it was maintained by tributes and gifts of agricultural products; and it was either strengthened or weakened by the perpetual petty warfare that tended to plague the islands of East Indonesia. In line with this, Andrew McWilliam has recently suggested that groups used the ubiquitous custom of headhunting to build up a position of political centrality (McWilliam 1996). At the same time, the data for the pre-1900 period suggest that power was seldom stable. The VOC documents abound with conflicts concerning the borders of the princedoms and, sometimes, their sub-divisions. The documents also show that the smaller groups within the princedoms had a strong tendency to vote with their feet if the political leadership was not to their satisfaction. While migrations of dissatisfied groups of people are known to have taken place in central agricultural regions like Java, the lack of labour-intensive sawah cultivation presumably facilitated the numerous Timorese movements (Ricklefs 1981:500-1). Over the centuries, a large number of Timorese groups offered to submit to or ally themselves with

\footnotetext{
5 Fox 1999:10 notes that it was common among ruling Atoni clans to marry off their male members into various settlements within the territory. In accordance with the Timorese system, the wife-giving clan would enjoy a position of symbolic precedence, but equally, they would be politically attached to the ruling clan.
} 
the Dutch on Timor in order to fight off an obnoxious overlord, which is illustrative of the way in which allegiances could quickly change. There are also cases of 'men of prowess' who built up an individual power base and went against the established adat ${ }^{6}$ The principles of the society's structure may suggest a self-perpetuating system, but in practice they were quite regularly violated.

H.G. Schulte Nordholt in particular based his study on Insana, a Dawan-speaking princedom in the north of West Timor, thought to display archaic features until a late date - colonial rule was only implemented in 1915. Before discussing the variation in Timorese political organization, it is worth summarizing his findings. In symbolical terms, the domain was organized according to spatial orientation, ritual opposites and kinship units. The basic territorial unit was the hamlet, known as kuan or lopo. A hamlet would be inhabited by the lineage of a clan, called ume (a word also meaning house, compare to Malay rumah). This clan worked an area of land, using it as directed by a tobe, or custodian. H.G. Schulte Nordholt found traces of a quadripartition where theoretically four hamlets would form a village, although the reality did not usually conform to the theory. The head of a lineage was known as amaf, and one of these amaf would also serve as the tobe for the whole village. ${ }^{7}$ Such a person was known in European accounts as a temukung, a term that is actually derived from the Malay-Javanese noble title tumenggung. Some eight to twelve villages in turn constituted one quarter of the princedom of Insana. These quarters were originally led by the so-called four fathers, each of which was titled amaf naek, meaning 'great father'. They were genealogical headmen who were at the same time tobe naek, 'great custodians'. This meant that they controlled land in their quarter and oversaw the rituals emanating from the princely centre. One of their tasks was to collect poni pah, harvest gifts for the centre. In colonial times the Portuguese gave them the title of kapitan, 'captain', ${ }^{8}$ but generally, VOC sources about Timor are vague regarding titles; they variously speak of grand temukung, regents or even sub-kings, by which they probably mean amaf naek, but which could also refer to usif, 'noble assistants of the palace'.

\footnotetext{
6 Some cases from the late eighteenth century will be discussed in Chapter X. Indigenous traditions about migrations of Timorese groups are found in Middelkoop 1952 and Middelkoop 1968.

$7 \quad$ H.G. Schulte Nordholt 1971:186-8; Schulte Nordholt 1947. Insana is also studied in Cunningham 1965.

8 H.G. Schulte Nordholt 1971:190. Kapitan derives from the Portuguese word capitão.
} 
These four components then formed the two halves of the realm. Finally, in the centre of the princedom, between these two halves, lay the sonaf, the ruler's residence. It was quite in accordance with his ascribed role that he was known as atupas, 'he who sleeps'. At his side he had an executive palace chief, known as kolnel, 'colonel', yet another Portuguese concept. Moreover, four lords or usif, one per quarter, also assisted the princely centre of the ruler. The usif originally lived at the centre, as can be seen by the placement of their sacrificial poles (tola ana). These items, essential to the rituals, were placed around the large sacrificial pole of the ruler. Clark Cunningham has pointed out that the lordship of Insana 'united clans in a territory but should not supersede their interests, and compensation between local lineages, not fines to the lord, resolved disputes' (Cunningham 1965:375).

After the implementation of colonial rule in the early twentieth century, much was changed in the princedom. The usif became district heads or fettor at the expense of the amaf naek. Meanwhile, the old kolnel lineage was ousted from power while a new powerful lineage, Taolin, became officially appointed rajas; the old atupas line faded into relative obscurity. It is evident that the Dutch of the late colonial period preferred a bureaucratic structure, and a raja with executive powers (H.G. Schulte Nordholt 1971:189, 212, 227-9).

This brief summary leaves out many niceties of the system, but may give a rough idea of how a 'traditional' princedom might have been organized. It is nevertheless important to remember that different domains could exhibit considerable variations. In Amanuban, another Atoni princedom that has been studied by Andrew McWilliam, there was no diarchic structure at the centre - a 'female' ritual ruler and a 'male' executive regent - at least not by the nineteenth century. Rather, the ruler controlled the ritual functions that were understood to guarantee prosperity in the realm as well as active governance. The usif were controlled by the ruler, and the four amaf naek could not secure a strong place within the domain. This variance may be due to political reshuffling; traditional stories suggest that a new dynasty of Rotenese origin seized power in the past, possibly in the seventeenth century. ${ }^{9}$

The system of governance was also dependent on the local inheritance system. Throughout Timor, the position of the mother is an im-

$9 \quad$ McWilliam 2002:65-6. My own findings indicate that a ruling line might have expired c.1736 when the Amanuban elite approached the king of Amabi to be their suzerain lord (VOC 2383 [1736], f. 108). 
portant factor in determining the inheritance of a lordship, as is clearly demonstrated by records from the VOC period. The Helong and Atoni peoples of West Timor have a system that is basically patrilineal, but where the relationship between the bride-giving and bride-taking family (with a Malay-Tetun term, barlaque) is of prime importance. ${ }^{10}$ This is visible in the princely pedigrees that have been preserved; certain noble families had the privilege of providing a prince with a bride, generation after generation. As was the case in much of the archipelago, a marriage bestows a symbolic precedence on the family giving away the bride visà-vis the new family. The bride-price, belis, is a part of all this: failure by the bride-groom and his family to pay a substantial belis over a period of time means that the children of the marriage can be claimed back by the bride's family - in other words, a matrilineal feature within a patrilineal system. Documentary sources reveal that not even princely families were spared from such claims. ${ }^{11}$ It was also a common practice that one child in a set of siblings was returned to his, or her, maternal clan as a part of the marital exchange (Fox 1999:9). Among the Tetun of South Belu, where Wewiku-Wehali is situated, the system is clearly matrilinear, but sometimes, as with the Bunaq of Central Timor, the system contains elements of both.

Can these domains, therefore, be termed 'kingdoms' or 'early states', and their lords 'kings'? A comprehensive debate has surfaced about the early state in recent years, and one may do well to refer to Henri Claessen and Jarich Oosten's discussion of the formation of early states. As they point out, the manner in which early states were governed depends on a system of delegation of tasks and power. In such a system, the central leaders and the local leaders vie for power, the former favouring centralization whereas the latter favour decentralization. This will result in the search for a balanced system, but also in competition for offices. Claessen and Oosten point out four basic conditions that enable a state organization to develop (Claessen and Oosten 1996:4-5). Firstly, there should be a sufficient number of people to form a complex and stratified society. This criterion is partly fulfilled in the pre-1900 Timorese domains, in

\footnotetext{
1o Barlaque derives from Malay berlaki, 'to be married to a man'. Note that barlaque was important in other parts of Timor as well. For convenience sake, the term is used in this book on a Timor-wide level. 11 ANRI Timor:59, Register der handelingen en besluiten, sub 29-4-1850, cites a case where three princes of Amanuban became princes of Sonbai, since the belis had never been paid for their mother, Maria Elizabeth Nisnoni of Lesser Sonbai.
} 
respect of which there is detailed information available. Although the population merely consisted of a few thousand people, or, at the most, tens of thousands, an elaborate hierarchy of offices and lineages can be discerned. Whether the Timorese system included a 'nobility' has been debated, since not all members of a clan that produced usif or amaf naek retained a privileged status. At any rate, it is clear that genealogical factors were decisive in determining the status of an individual, so that social stratification and political hierarchy paralleled each other. ${ }^{12}$

A second condition is control over a particular territory. This does not mean that the territory is self-sufficient; control over an insufficient area of land may motivate expansion and conquest. Here, too, the Timorese domains partly match the prerequisite condition. As in several areas of the archipelago, the polity was based on a number of personal relationships and a greatly fragmented control over manpower, held together by a ritualized system (Henk Schulte Nordholt 1996:4-11, 149). The exact area of settlement was constantly changing in response to political and economic opportunities, but the documents also point to an awareness of the borders of the realm. The Timorese informers would, at times, describe border claims in great detail to their Dutch allies. This is also demonstrated by the existence of gate (pintu, eno) settlements that mark the boundary markers of the princedom or the smaller district. ${ }^{13}$ As remarked by Jim Fox, domains mentioned in the sixteenth century were still viable entities in the twentieth century, showing the ability of the polities to survive and maintain strong links with the land (Fox 2000:18).

Thirdly, there should be a system that harvests part of the production surplus and distributes it to those carrying out specialized roles and the privileged groups. Such a system indeed occurred in the Timorese princedoms, where ritualized harvest gifts are mentioned as far back as the mid-seventeenth century, as are the contributions, called tuthais. A

12 H.G. Schulte Nordholt 1971:382. For Belu, Vroklage (1953, I:547) has noted the distinction of the noble 'estates' (Standen) known as dasi (the full-fledged princely persons) and usi (the lords of lower rank) vis-à-vis the broader strata of society. The bona fide dasi must have had princely blood on the paternal and maternal side. Likewise, in 1760, the executive regent of Greater Sonbai emphasized to the Dutch the importance of the ruler being of good blood on both sides: 'According to our laws nobody can become an emperor who is not sprung from royal blood on the side of the father and the mother' (VOC 2991 [1760], n.p.).

13 Compare McWilliam 2002:111. The border between the VOC-Helong complex and Amarasi was carefully delineated in a report from 1692. From north to south, it purportedly ran via Oypahak, Icanfotty, Fattoemetan, Wanilawa, Wonnameke, Oynenopotty, Omackphenou, Tuaha, Massipalak, Fattoeheo, Waemina, Nimanette, Taymettan, Pilinaussy, Tamwenno, Poukay and Asiasi (VOC 1516 [1692]). 
comprehensive system that involved the various levels of society had therefore evolved before the onset of colonial influence. The sandalwood trade generated income for the elites, which in turn encouraged a system that made the local settlements collect wood, or, failing that, beeswax, honey, gold, turtle-shell and slaves.

Last but not least, the development of a state demands an ideology that offers a rationale for the unequal distribution of wealth and the existence of hierarchies and elite groups. On the one hand, ideologies may be seen as superstructures of a material, socio-economic base; on the other hand, they can be considered a central element in the evolution of a socio-political system, highly embedded in society. In that sense, they are on a par with the economic, demographic and economic aspects of a community (Claessen and Oosten 1996:15-6). In terms of Timor, ideologies are elaborated in ways which have been explored in substantial detail by H.G. Schulte Nordholt (1971), Parera (1994) and Neonbasu (2005). As exemplified by Biboki on the north coast, the king is the centre of a symbolic complex, which sees him as the 'trunk', a central figure that brings good life and blessings. In this capacity, he embraces the cosmos throughout his lands and does not err in his actions. He is thus a sacred and superior figure, yet at the same time, is expected to act humbly and benefit the people (Neonbasu 2005:198-203). This suggests an imagery of lordship that goes further than the level of chiefdom.

The lack of literacy motivated a comprehensive bank of oral 'knowledge' about the past, what may be termed myths and legends. This body of knowledge set out the origins of the current order of society. In the parochial outlook of the subjects of the Timorese domains, such narratives explained the founding of a princedom, the origins of a ruler, the establishment of the usif families, the relation between the elites and the local communities, and so on. Such narratives were not fixed, but tended to alter its contents according to the circumstances; in this way, the performance of oral tradition was a highly political act. It was also institutionalized, so that particular spokesmen and tradition experts mafefa among the Atoni, makoan among the Tetun - were entrusted the task of preserving the 'correct' version. The idea that the current order of a polity was founded in mythical conditions is very common in the eastern part of the Southeast Asian Archipelago (Therik 2004:77).

In sum, Timorese polities, for all their internal competition, contained elements which in certain respects placed them in the early-state 
category. ${ }^{14}$ Considering their small and non-centralized character, the terms 'princedom' and 'domain' will be used throughout this work. In accordance with contemporary European usage, the heads of these princedoms will be termed 'kings' in order to clearly distinguish them from the executive regents. The most detailed material for the pre-1900 situation pertains to the western princedoms, which tended to be larger than the eastern ones. Whatever early Portuguese material there is at hand, however, suggests that the basic organizational framework was comparable throughout the entire island. ${ }^{15}$ At the same time, it must be emphasized that the administrative details and capabilities of the elite were altered during successive centuries. In a way, the rulers became 'kings' or 'rajas', or even 'emperors', because the foreigners chose to honour them as such. As mentioned earlier, the increase in the trade of sandalwood must have altered conditions in the coastal princedoms, since it provided new sources of income for the elite. The same goes for the import of Portuguese-Catholic symbols of authority, which were soon deeply embedded in collective values and underpinned the position of the elites in various ways. The Dutch influence after the midseventeenth century was important in defining the power capabilities of its local allies. The dissemination of firearms could either strengthen or, equally, eradicate the princedoms. Finally, with the dawn of the twentieth century, the colonial authorities deconstructed the princedoms in East Timor, and transformed them into zelfbesturende landschappen (selfruling territories) in West Timor, motivated in both cases by concerns of colonial exploitation and governance. This, however, is a process that cannot be described in detail in the present work. ${ }^{16}$

\section{WEHALI - THE CENTRE}

Hitherto, we have spoken of Timorese polities as being comparatively small, a feature they share with most regions of the eastern archipelago. However, there were also politico-ideological structures that surpassed

\footnotetext{
${ }^{14}$ In the same way, Andrew McWilliam, working with late colonial sources, argues that 'the concept of state, or some allied form of federated political order, has a tradition in Timor that predates colonial meddling' (McWilliam 1996:162).

${ }_{15}$ See in first instance Ospina and Hohe 2002:17-37; Traube 1986.

${ }_{16}$ In an Indonesia-wide context, the process is chronicled by Bongenaar 2005.
} 
the limited area of the princedom. Like the Minangkabau kingship of Pagaruyung in Sumatra, and the Dewa Agung of Klungkung on Bali, they were 'kingdoms of words', which to the colonials seemed to be irrelevant and lacking in real authority, but which did enjoy a lasting importance in regional political culture (Wiener 1995; Drakard 1999). In terms of symbolic classification, the most important polity on the island was Wehali or, to use its double-barrelled name, Wewiku-Wehali. In the first place it represented the Tetun people who settled in Central Timor and parts of East Timor, and who enjoyed a politically and culturally prominent island-wide role. By extension, Wehali was considered the 'navel' of Timor, and its ritual origin-house is conceptually the origin-house of the peoples of the world (Therik 2004:91-3, 175).

Considering the turbulent history of the island, Wehali may seem an unlikely location for a central place. It is situated in the alluvial plain in southern Central Timor, in the modern regency of Belu, an area suitable for the cultivation of a variety of crops; it therefore has good economic preconditions in comparison with other parts of Timor (Therik 2004:33). These advantages have no doubt contributed to the prominence of Wehali in historical terms. However, the flat land is difficult to defend and lacked fortifications. It is regarded as 'female' land (rai feto), which is in opposition to the surrounding 'male' mountain territories, and the likewise 'male' ocean in the south. In spite of violent interventions by the Portuguese (in 1642, 1665, 1677 and 1759) and the Dutch (in 1899 and 1906), its female character has not abrogated its great symbolic importance. On the contrary, its function as a revered ritual centre has apparently helped to preserve it, though it has certainly not emerged unscathed.

Pre-1900 data on Wehali are rare and often vague. From twentiethcentury materials, however, a detailed picture can be reconstructed of the 'traditional' institutions of the realm. Unlike the common Timorese pattern, the Tetun of South Belu were matrilineal, and the inheritance of political positions was an intricate matter which has had implications right through to the present day. ${ }^{17}$ In the very centre, in the village of

${ }_{17}$ In particular, one may refer to the conflict that arose after the death of the last liurai of Wehali in 2003. An early claimant to the (nowadays symbolic) position was met by counter-claims, causing him to leave the village of Laran, the centre of the realm. Personal communication with local informants, Belu, February 2008. 
Laran close to Betun, was the great lord of the realm, maromak oan. ${ }^{18}$ The title means 'the son of God' and points to his role as a ritual head, watching over a set of sacred objects. He was the archetypical inactive ruler, expected to keep the system in place by resting at its centre - 'the one who eats reclining, who drinks reclining'. He was the 'dark lord', a term that does not carry negative connotations, but means that he represented the earth - a 'female' entity in contrast with the 'male' heaven. ${ }^{19}$ While retaining the supreme authority in the centre, he delegated power to realms in other parts of Timor (Fox 1982:26). In early colonial documents the references to a 'king of Wehali' are ambiguous, and most probably refer to the executive ruler of the realm, the liurai. The office of maromak oan is only described in reports from the late nineteenth century onwards, which demonstrates the poor European knowledge of Timorese ideologies in general, and Belu in particular.

The liurai was the active, 'male' lord of Wehali. In contrast with the maromak oan he was the 'visible lord' through whom contact was maintained with the outside. The term means 'surpassing the earth'. In modern times it has been used in Portuguese East Timor to denote rulers in general; however, its use originally seems to have been much more restricted. Before the late eighteenth century, it appears to have only occurred once, and then in the form 'lieuw lay' (liulai, a side-form of liurai). In July 1732, the ruling queen of Belu was referred to by this title when she sent an envoy to the VOG in Kupang. ${ }^{20}$ In the legends of the Atoni of West Timor, the term liurai refers to the ruler of Wehali in particular. Liurai-Sonbai is moreover a conceptual pair among the Atoni, where the two dynastic terms denote rice and maize, the basis of the Timorese farming economy. At least by the early nineteenth century the rulers of the Atoni Sonbai dynasty were themselves known as liurai - but this did not apply to any other Atoni princes. A widely disseminated version of history talks of an early maromak oan, the father of three sons who became the liurai of Wehali in Central Timor, Sonbai in West Timor, and

18 A pedigree of the maromak oan is found in Munandjar Widiyatmika 2007:51, drawn from a document from 1928. It only encompasses eight generations and does not quite agree with the disparate Dutch materials. When I visited Laran in January 2005, Dominikus Tei Seran, the claimant to the liurai title, gave me a list of maromak oan which was at complete odds with Munandjar Widiyatmika's. It is somewhat surprising that the essential ritual role of the title has not ensured more precise and stabile traditions about its history; the contrast with Sonbai in West Timor is apparent.

19 Therik 2004:xvi-xvii. Regarding the impossibility of elevating the maromak oan to an effective executive function in the late colonial period, see Francillon 1980:252-4.

2o $\quad$ VOC 2239 (1732), f. 109-10. 


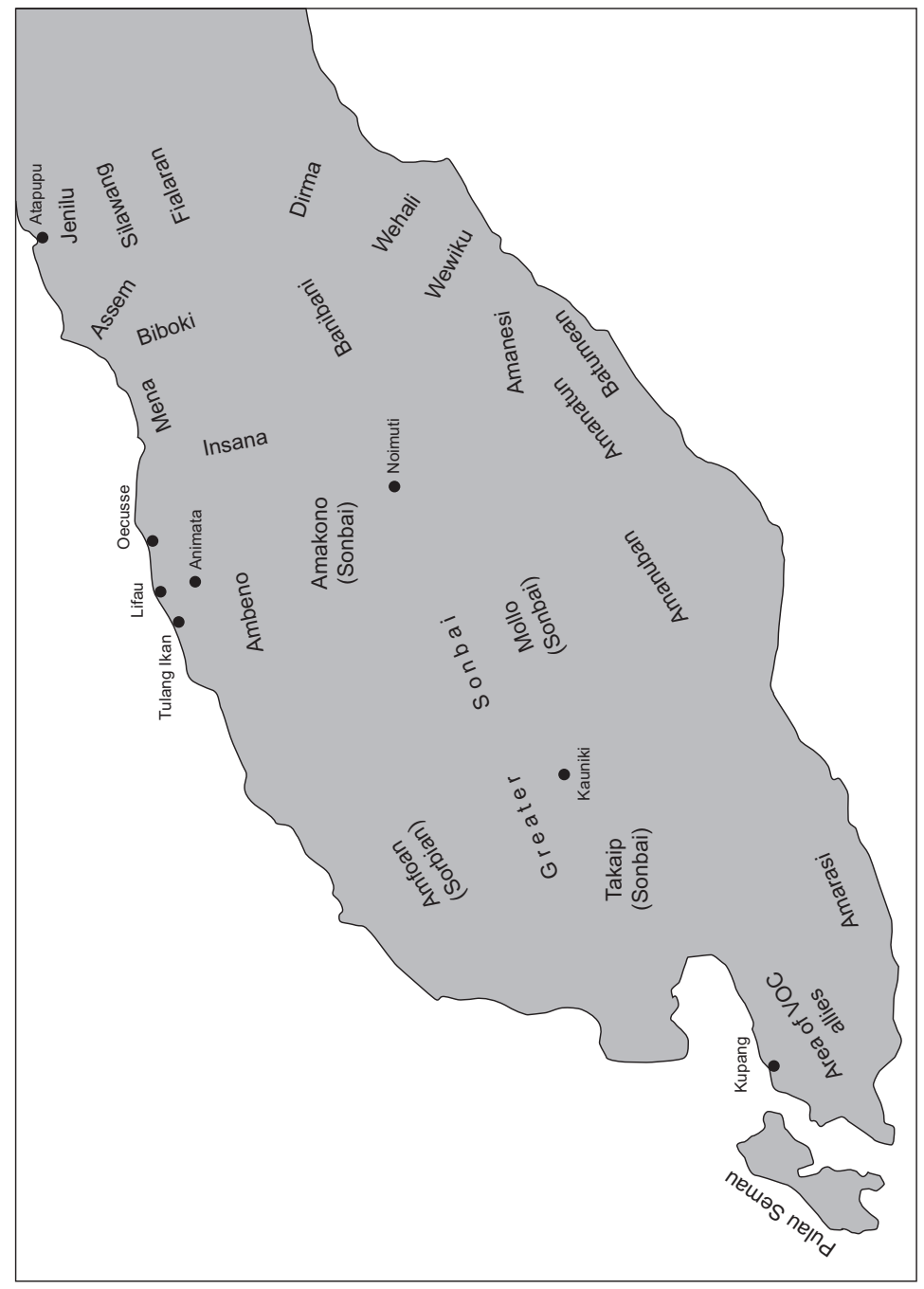

West Timorese domains 
Likusaen in East Timor. ${ }^{21}$ The three liurai were therefore the 'assistants' of the maromak oan, who took charge of the three parts of the island. In that way, Wehali constituted the theoretical origin-point of Timorese kingship.

The origins of the prestige enjoyed by Wehali are shrouded in contradictory myths and legends. One origin myth claims that the world was covered with water in primeval times, and that Marlilu, in Wehali, was the first land to appear when the water receded. This circumstance gave Wehali a status of being the central point of the lands. ${ }^{22}$ As noted above, in insular Southeast Asia, and especially in the eastern part of the archipelago, the notion of a 'stranger-king' is important. The exact origin of the immigrants to Belu is a moot point. An early document from 1836 argues that the Belu were descended from Jailolo (Halmahera) in Maluku (Kruseman 1836:15). This is interesting considering the hypotheses about early Central Malayo-Polynesian migrations from northern Maluku. These hypothetical migrations would have occurred over a very long period of time, and may have left an awareness of their distant origins in the collective memory of the old Indonesian heartland (Granucci 2005:41). On the other hand, stories recorded in the twentieth century single them out as Sina Mutin Malaka, 'the White Chinese of Malacca'. This group of people supposedly set off from Malacca on one occasion in order to find new means of earning their livelihood. Bringing sacred items from their homeland, their boats eventually arrived at the fertile plains of South Belu, via Makassar and Larantuka. At that time, the land was inhabited by the Ema Melus, aborigines armed with bows and arrows. These were easily worsted and expelled, and the newcom-

${ }^{21} \quad$ Spillett 1999:344; Fobia 1984:10-8; H.G. Schulte Nordholt 1971:391. An early version, which speaks of kings (reis) rather than liurai, is found in a document from 1734 (Castro 1867:242-3). As discussed below, the tripartition Wehali-Sonbai-Likusaen is sometimes replaced by Wehali-Sonbai-Camenaça or Wehali-Sonbai-Luca (Francis 1838:393). In West Timor there are other enumerations, which include a variety of local Atoni ancestors among the brothers. However, the components 'Wehali' and 'Sonbai' always appear.

${ }_{22}$ Interview, Dominikus Tei Seran, Laran, 30-1-2005; Vroklage 1953, II:140; compare Munandjar Widiyatmika 2007:37-64, 109. One of Munandjar Widiyatmika's sources says that a woman, Laka Lorok Meak, first appeared on Gunung Lakaan, which is actually in North Belu, some distance from Wehali. Her two sons and two daughters married each other, and one pair founded Naitimu. The other pair begot ten grandchildren who were established in Flores, Biboki, Insana, Lidak, Lakekun, Maucatar and Fialaran. Wehali itself was thus left out of this North Belu origin myth. In modern times spokesmen from this area have tried to downplay the precedence of the maromak oan institution. Nevertheless, Dutch documents from the nineteenth century clearly suggest that Fialaran, Lidak, and so on, were subjected to the symbolic authority of Wehali (ANRI Timor:54, Register der handelingen en besluiten, sub 9-5-1844). 
ers expanded their influence over the island (Grijzen 1904:18-9; Therik 2004:53). The exact meaning of Sina Mutin Malaka is far from clear, and at the moment there is no way to tell when the migration took place, as the pedigrees of the liurai and maromak oan vary too much in terms of their content to allow conclusions to be drawn. If the very name is assumed to reflect historical reality, it would suggest the period between the founding of the Malacca kingdom in circa 1400 and the first mention of Wewiku(-Wehali) in 1522. The Dutch writer Grijzen in 1904 believed that there was indeed substance to the claim of a Malacca connection since there were similarities in the respective adat of South Belu and Malacca. Nevertheless, one should note that the Tetun language is not closely related to Malay, in spite of numerous loan-words, but rather is closer to Polynesian languages. ${ }^{23}$ If migrations did take place, it would likely have been only a small group, albeit one of potential cultural significance.

What is certain is that the Tetun-speaking population on Timor enjoyed a historical precedence. The elite of most of Timor are connected to Wehali in one way or another, and even where there was little actual contact, the oral tradition of the princedoms of the east and the west referred to Wehali as the ultimate point of reference. It has been concluded that a military Tetun aristocracy subjugated Central and East Timor, subsequently introducing their political-ritual system over the island. This conclusion is supposedly strengthened by traces of a superimposition of the Tetun-speaking aristocracy, the datos belos, on an earlier theocratic local nobility (Thomaz 1981:58). Among the Atoni of West Timor, too, the aristocracies claim to have descended from Belu, in particular Wehali.

In spite of the exclusive position of Wehali, its immediate sphere of power was not large. In the centre of the South Belu plain lay a nucleus of four princedoms, in line with the usual structuring principle of quadripartition. The Sina Mutin Malaka encompassed four sub-tribes, who settled in Wehali, Wewiku, Haitimuk and Fatuaruin. Of these, Wewiku was the strongest component, the foremost 'post' of Wehali, although it was not always on good terms with it. Fatuaruin was the seat of the executive lord, the liurai, who is usually referred to as the liurai of Wehali.

\footnotetext{
23 Thomaz 1981:59. Vroklage (1953, II:153-4) assumes that the concept of Sina Mutin Malaka arose from old trading relations, where the Chinese would be associated with the colour white because of their comparatively fair skin.
} 
Outside this 'female' land lay three further Tetun domains to the east and north, called Lakekun, Dirma and Fialaran. The lords of these princedoms bore the title of loro, or 'sun'. All of the historical documentation that remains, implies that while Wehali had a strong claim to authority over these lands, it also had continuous conflicts with them. Further away, on the north coast, lay three other loro-ships that were also subjected to Wehali influence, although they were not Tetun, but Atoni or Tocodede. They were Insana, Biboki and Maubara. Even more remote, the liurai of Sonbai and Likusaen, alternatively Suai-Camenaça, accorded Wehali a position of precedence, although the consequences of this were both subtle and indirect.

Nevertheless, Wehali will not, unfortunately, hold a major place in a study of seventeenth- and eighteenth-century Timor. This is not due to any lack of importance, but rather to the nature of the source material. The Dutch as well as the Portuguese had limited interest in the traditional power structures, except when it concerned their own implementation of power. The relative lack of references in the documents shows that neither group made much effort to establish their interests in South Belu. The Portuguese did, however, instigate a rough geographical division of the island into two major 'provinces', namely Servião and Belu. These two terms are found in texts from the seventeenth century. In later documents, there are long lists of reinos, which were attributed to either province. $^{24}$

Roughly, Servião encompassed the Dawan-speaking Atoni lands in the west plus the Helong domain of Kupang. Although the ethnic terms Tetun and Belu are approximately interchangeable, the province of Belu did not just include the Tetun domains; it also encompassed all the domains in the east, where some fifteen different languages are spoken. ${ }^{25}$ An early report from 1702 asserted that Belu constituted 'the major part of this island' (a mayor parte desta ilha) (Matos 1974a:229). This inclusive geographical concept can be partly explained through the position of Tetun as a lingua franca of the central and eastern parts of the island - a vehicular language, to quote Thomaz (1981:54). With the exception of

\footnotetext{
${ }^{24}$ The intricate question of the origins of the terms 'Servião' and 'Belu' has been discussed in Hägerdal 2006.

${ }_{25}$ Hull 1998:1-4 has identified nineteen languages on Timor and off-shore islands. Omitting Ndao, Rotenese, Helong and Atoni, which are not spoken in the eastern half, that would make fifteen. The linguistic map in Durand 2006b:47 shows seventeen languages in the east.
} 
the Fataluco-speaking eastern tip of the island, Tetun was normally used as a second language in these areas. That must have been the case by the time the Europeans arrived, as seen from the mistaken belief that the eastern lands spoke one language. This is found in a missionary report from the second half of the seventeenth century: 'In this island of Timor, there are only two languages, distinct from each other, which are called Vaiquenos [Dawan] and Belos [Tetun]. ${ }^{26}$

The Portuguese use of the term Belu ultimately derived from the political and cultural prominence of the Tetun, and as such it was a colonial device. The enumerations of reinos in the Portuguese documents did not include the all-important Wehali. Rather, this polity was included in the other major 'province', Servião. Why this occurred, is hard to say. Perhaps the prestigious Wehali seemed more akin with the larger Atoni domains of the west than with the small reinos of the east. A Portuguese document from 1727 discussed possible ways of strengthening colonial dominance through the establishment of strongholds, further commenting about Wehali:

Besides, more can be done in the lands of Vayale [Wehali] (part of the Provincia do Servião), namely a frontier trench of that province, well settled to cool down the enemy, the Larantuqueiros; and it will be much better than any inlet that can be made, and it is not very distant from Batugade and has the best security. That government delivers more respect than other ones that conspire against it. (Faria de Morais 1934:67.)

The quotation implies that the Portuguese clearly understood the centrality of Wehali, and used this knowledge to prop up the precarious Portuguese authority. Astonishingly, Wehali was believed to have 'the best security', notwithstanding its vulnerable situation on the South Belu plain, something which may be explained, in part, by the great authority that Wehali still enjoyed, despite its political weaknesses. A few decades later, the Dutch opperhoofd in Kupang would point out Wehali as the 'key' to appropriating the Belu lands. ${ }^{27}$

26 Loureiro 1995:147; see also Hägerdal 2006:52n.

${ }_{27}$ VOC $8346(1753)$, f. 43. 


\section{SONBAI}

When speaking of the western province of Servião, there is an oftquoted passage from the 'Instrucções do Conde de Sarzedas', a lengthy memorandum written for the incoming Portuguese governor of Timor in 1811:

The island of Timor is populated by native inhabitants, with a distinction between the Bellos [Belu] and the Vaiquenos [Dawan-speaking Atoni], in opposition to each other. They constitute, so to say, two provinces and two nations. In the eastern part the Belu inhabit the province called Belu [a provincia denominada dos Bellos], and in the western part the Vaiquenos inhabit the province called Servião. These two provinces are divided in kingdoms; Belu comprehends 46 more or less powerful ones, but all are free and independent among them, and have, according to lists drawn up in 1722-1725, 40,000 armed men, 3,000 [of whom carried] shotguns and the rest swords, cutlasses, assegais and bows and arrows. The province of Servião has got 16 kingdoms, which all recognize as their superior Senobay [Sonbai] with the title of emperor [imperador], who is king of the Kingdom of Servião, from which the province has taken its name. This province has got 25,000 fighting men, 2,000 of whom were armed with shotguns and the rest with assegais, bows and arrows, swords and cutlasses. In that way the whole island of Timor is divided into 62 kingdoms, besides the Kingdom of Kupang which is at the southern point of the island, where the Dutch have their fortress that bears the name Kupang. [...] Over the whole of the island is produced sandalwood, beeswax, cotton, tobacco, wooden containers, sea animals, kauri, rice, large corn, beans, corn, tamarinds, large cinnamon, coconuts, ginger, saffron, long pepper and salt. (Castro 1867:185.)

In this document, West Timor is an 'empire' where the so-called Vaiquenos, the Dawan-speaking Atoni population, all pay their respects to the overlord of Sonbai. In this way it parallels the nomenclature of other colonial texts from the seventeenth and eighteenth centuries. The Dutch as well as the Portuguese insisted on employing the title of emperor (keizer, imperador) for the ruler, which obviously set him apart from the other lords on the island. Up until the late eighteenth century, when the title of 'keizer' diminished in importance, there was no other 'keizer' 
than the lord of Sonbai noted in the Dutch documents. Likewise, the Portuguese reserved the denomination 'imperador' for the ruler of Sonbai and, occasionally, the ruler of Wehali. ${ }^{28}$

There are a great number of oral narratives concerning Sonbai in West Timor. Together with the liurai of Wehali, the Sonbai lord is a major point of reference and holds a place in the ritual language. Liurai-Sonbai are substitute words for maize and rice, the basic crops of the peasants, and according to a widely propogated myth, Liurai-Sonbai gave the people their main agricultural crops through a human sacrifice involving a sister, or a female relative, of the two figures. The body of the woman changed into maize, rice and other useful products (H.G. Schulte Nordholt 1971:55, 271). The reputation of the Sonbai lords in folk tradition is somewhat ambiguous. They are culture heroes who are deeply embedded in the Atoni view of a mythical past. There are at least three sacred places on West Timor where sacrifices are performed and prayers said to the Sonbai lord, one of which is situated at the rock of Kauniki, one of the old historical strongholds of Sonbai, which is also seen as the 'navel' of Timor. As late as 1927, several decades after the end of Sonbai rule in the inland of Timor, a grand sacrificial ceremony was held in order to ask Sonbai for help against an invasion of mice that destroyed the harvest (Middelkoop 1938:403-4). At the same time, however, there are stories that depict the Sonbai lords as a negative force, emphasizing their cruel and despotic features.

It is clear that Sonbai enjoyed a political precedence, but this, again, must be seen in terms of status rather than conventional political power. The Sonbai lands encompassed extensive territories in the inland of West Timor, more or less corresponding to the later landschappen of Fatuleu, Mollo and Miomaffo. However, the realm was cohesively weak, despite a few individual rulers who stood out in the sources as being personally active. Nevertheless, the Sonbai ruler generally followed Timorese political conventions, and was seen as an inactive figurehead. He was known by the titles of neno anan (son of heaven) or atupas, or by

${ }_{28}$ When speaking about the ruler of Wehali, the early colonial records are not clear. In general, it is not obvious whether the maromak oan or the liurai is referred to - although one can assume that it is the latter - as the active component in the diarchy is alluded to in most cases. When the missionary H.A. Jansen met the maromak oan in 1892, the latter was also known as kèser, 'emperor' (Jansen 1893). The word is derived from the Dutch word keizer and must have been introduced later, after Dutch political influence began to disseminate in the latter half of the eighteenth century. 
the Belu term liurai. ${ }^{29}$ In his capacity as liurai or assistant to the maromak oan of Wehali he was 'male', but as the head of the Sonbai congregation he was 'female'. The executive powers of the realm lay with the 'male' regents that belonged to the Kono and Oematan families. The powerful position of the first regent is denoted by the term Amakono (Father Kono), which was often used as a synonym for the Sonbai realm. The other Atoni princedoms did not usually pay homage to the lord of Sonbai, let alone obey him, although most of them saw themselves as related to the ruler in genealogical terms.

According to the extant legends, the origins of Sonbai are twofold. One version states that the first lord descended from the lord of heaven (Uis Neno). Appearing on earth, he improved the means of livelihood of the people, cementing his role as a culture hero. However, there is also a longer account of the early stages of the dynasty, which can be summarized as follows below. This version is the one told within the princely family in the twentieth century; it was committed to paper by the local scholar F.H. Fobia (1984). ${ }^{30}$

The story begins with the migration of a Tetun elite group from Wehali, which was led by Nai Laban, also known as Nai Dawan. He was an eponymous ancestral figure representing the Dawan-speakers, or Atoni. He was the second of three brothers, sons of maromak oan. His elder brother, Nai Suri, was the forefather of the liurai of Wehali, while the youngest brother, Nai Taek, was the ancestor of the East Timorese liurai-ship Likusaen (Liquiça). There are other versions of the story, the oldest ones being those written down by Salomon Müller (1829) and Geerloff Heijmering (1847), but all emphasize that the Sonbai ancestor was the brother of the Wehali liurai.

Nai Laban, valiant by nature, was dispatched by the maromak oan in Laran to secure the source area of the rivers that flowed down to Belu. He entered the hilly area in the company of six chiefs and their followers. These chiefs then established themselves in various parts of West Timor, and their congregations were thus the nuclei of the later Atoni domains.

29 These titles are only known from relatively modern writings. VOC documents only refer to the Sonbai lord as 'keizer'. The Belu title 'liurai' for the Sonbai lord is documented from the 1820s onwards (Müller 1857, II:145-7).

$3^{\circ} \quad$ F.H. Fobia is the son of Nikodemus Fobia, who was the mafefa for Tua Sonbai, raja of Mollo (died 1959). Fobia received information from his father and the raja, and furthermore interviewed some 30 experts on tradition in the inland of West Timor. His account is therefore a digest, and presumably representative of the extant stories. For a published, abbreviated version of this, see Wadu et al. 2003:17-65. 
Having surveyed the vast western areas, Nai Laban had a meeting with his elder brother in Wehali at the river Noel Bi Lomi, where his elder brother agreed to his right to govern over the mountainous lands. After some time, the immigrant lord passed away at Noel Bi Lomi. His son, Nai Natti, took over his prerogatives and maintained the bonds with Belu by marrying a lady from Besikama, situated on the southern plain. After residing in Humusu for some time, Nai Natti fell ill, but prior to his death he commanded his adolescent son, Nai Faluk, to continue expanding in the highlands, right up to the source of the Benain River. When the liurai of Wehali heard that the new lord of the hills was still young, he sent two assistants to help him maintain his authority. They were Fai Bele and Ifo Bele, who arrived in Humusu with numerous retainers and cattle (Fobia 1984:14-6).

Nai Faluk grew up to become a restless warrior, at one stage leaving Humusu in order to explore the mountainous lands. He departed on his horse, Bilu Oba, whose hoof-mark can still be seen on one particular stone - Timorese legends have a propensity to name animals, and to try and prove the veracity of a story by referring to natural occurrences. On his journey, Nai Faluk carried a lance, a sword and a collar that he had inherited from his forefathers. He explored the area around the mighty Gunung Mutis, which at 2,427 metres is the highest mountain in West Timor. As a sign that he was to govern the land, he lit a huge fire, the flames of which reached the sky. However, he had still not met any people. Blackening his body and equipment with soot in order to resemble the dark-skinned inhabitants of the area, he headed towards the Noebesi River, where at a spring he saw two girls drawing water. At first the two girls shrugged at the sight of the dark foreigner; however, as he washed away the soot, they became enamoured with the handsome young man. Realizing their feelings for him, Nai Faluk subjected the girls to a test. He asked the spirits of his ancestors for help, and thrusting his sword in a tree, asked the girls to pull it out. Only one of the girls, Bi Lile Kune, managed to do so, whereupon he thrust his lance into the ground. Again, she was able to pull it out whereas her sister failed. Nai Faluk then announced that Bi Lile Kune was the woman he wished to marry (Fobia 1984:16-20).

The father of the sisters was a local chief called Nai Ke Kune. Not only did he accept the marriage of his daughter to the newcomer, but he developed such a strong relationship with Nai Faluk that he subsequently 
named him his heir. The Kune family resided in Sabatu, but they also owned a residence on the slopes of Gunung Mutis, which was known as the House of Eight Pillars. Since it was situated at an altitude of 1,750 metres, it was too cool there to stay comfortably, and so the residence was given to the chiefs Nai Jabi (Amabi) and Nai Besi (Amabesi). On one occasion, Nai Faluk went together with Nai Ke Kune and his two assistants, Fai Bele and Ifo Bele, to see the House of Eight Pillars. When they stopped to rest, Nai Faluk asked Fai Bele to look for a spring to fetch water. Fai Bele failed to do so, but Ifo Bele was successful in locating the water. For that reason, Fai Bele was renamed Kono (to pass by), while Ifo Bele received the name Oematan (spring). When the party reached the House of Eight Pillars, however, Kono defeated Oematan in a spearthrowing contest, causing Kono (or Amakono, Father Kono) to become the first executive regent of the princedom, while Oematan became the second one. The two regents married sisters of Bi Lile Kune, which meant that the Sonbai, Kono and Oematan descendants were all united by blood ties (Fobia 1984:20-4).

After having received the lands of Kune, Nai Faluk sent a bamboo piece floating down the Noebesi and Benain rivers, all the way to Wehali. The bamboo contained a message in the form of a rebus, and reached the liurai of Wehali with the help of the ancestral spirits; the rebus message said that Nai Faluk had now created a princedom in the uplands. Perceiving this, the liurai was quick to send new migrants towards Gunung Mutis. They were the Timau and Belumau groups, who originated from next to the Bunaq lands in East Timor. The Timau headman was subsequently renamed Foan (Amfoan), while the Belumau headman was renamed Benu (Ambeno), and the two groups initially settled down on the heights of Paeneno-Oenam, where the House of Eight Pillars was situated (Fobia 1984:20-2, 24-6).

Nai Faluk's son and successor was Nai Lele. It was he who adopted the name Sonbai (Sona'ba'i, Sonba'i) for the dynasty. Folk etymology shows that the name derives from the name of one of the ruler's residences, which resembled a boat turned upside down (sonaf, princely residence; bai, boat). ${ }^{31}$ Meanwhile, Nai Lele Sonbai called his realm Oenam, after the eight-pillared residence of ritual importance that was

\footnotetext{
$3^{11}$ Müller (1857, II:151) shows Sonabai to derive from sona (stab) and bai (much). The various suggestions for the origins of the name Sonbai have been summarized in Munandjar Widiyatmika 2007:72-4. The only conclusion that we can draw from this is that the exact roots remain unknown.
} 
considered to be the centre of the realm. Nai Lele Sonbai in particular is portrayed as a culture hero; his name means 'plantation'. He ordered the population under his rule to settle down in fixed places, rather than roaming the mountains and forests. He also developed agriculture by teaching people to construct proper plantations, stopped erosion by using various devices, and developed ditches for rainwater. People were taught to cultivate maize, rice paddies, bananas and sugar-canes. Earth, rain, heat, and so on, were gifts from the Sonbai lord; for he was ulan tuan, manas tuan (lord of rain, lord of heat). Each year when the harvest was about to be collected, Nai Lele Sonbai, together with the people, would perform worship at Paeneno-Oenam with the following prayer: 'The buffalo reaches Paeneno-Oenam, the horse reaches Paeneno-Oenam, the ripe banana goes to Paeneno-Oenam, the ripe sugar-cane goes to Paeneno-Oenam' (Fobia 1984:32-6).

If Nai Lele Sonbai was the culture hero, then his son Nai Tuklua Sonbai was the warrior who expanded the authority of the Oenam kingdom by various means. He had magic properties, and could change into a stone, a tree or a python - an animal particularly associated with Sonbai. He also arranged a grand meeting at the river Noel Bi Lomi, to settle the spheres of influence of the liurai of Sonbai, Wehali and Likusaen. At the meeting, the various am uf or 'minor kings' of the Atoni people were present. The status between each of them and Sonbai was laid down according to a scheme which sets out the two Timorese means of defining precedence: via siblingship or barlaque relations.

Sonbai and Amanatun are like older and younger brother (tataf-olif).

Sonbai and Amarasi are like brothers-in-law (mone-feto).

Sonbai and Amabi are like younger and older brother (olif-tataf).

Sonbai and Amabesi are like younger and older brother (olif-tataf).

Sonbai and Amfoan with Ambeno are like older and younger brothers (tataf-olif). ${ }^{32}$

The Amabi and Amabesi groups guarded the Paeneno-Oenam Hill, but indicated that they wished to run their own affairs, causing Sonbai

32 Fobia 1984:36-40. Local genealogies and origin stories claim that the Amanatun, Amabi, Amfoan and Ambeno ancestors were brothers or close relatives of Liurai (meaning the kingship of Wehali) and Sonbai (Banunaek 2007:7; Middelkoop 1952:203; Heijmering 1847:27; personal communication, Diniz da Cruz, Oecusse, 13-1-2004). 
to order his Oematan regent to expel the two congregations from the hill, which he did successfully. The defeated lords led their followers to Gunung Mollo, a 2,070 metre-high mountain to the south of Gunung Mutis. The Amabi stayed on the mountain slopes, while the Amabesi group decided to move on to the west, and finally ended up in Kupang. Sonbai replaced the rebellious groups with two other communities, the Amfoan and the Ambeno, who settled at the prestigious summit. After a while, however, they too became conceited, and the Oematan regent was once again ordered to march against the rebellious groups. After some hostilities, both of them were obliged to leave the area and move towards the north coast, an area rich in sandalwood, honey and other commodities. The Amfoan settled down in the north-west, in the territory that henceforth bore their name; the Ambeno occupied previously uninhabited land, which now constitutes the Oecusse-Ambeno enclave of Timor Leste (Fobia 1984:43-5, 53-8).

The problems of Nai Tuklua Sonbai with the Amabi did not, however, end with these changes: at Gunung Mollo, the Amabi were joined by a related group from the land of Banam (Amanuban), and together, they became a formidable and expansive power. When they threatened a small domain called Lassa, the latter called for Sonbai assistance, which was readily given. After a military setback when a prominent champion was killed, the Amabi lord chose to jump to his death from the steep slopes of Gunung Mollo (Fobia 1984:46-8). With this very event, one may argue that we have moved from Sonbai protohistory to the beginnings of historical writing.

The death of the king of Amabi at Gunung Mollo is known to have taken place at the beginning of October 1657, though the circumstances described in Western documents are rather different from what is related above. ${ }^{33}$ It is worthwile pausing for a moment to consider this.

Naturally, the narrative above must not be seen as history in a conventional sense. Although historical particulars can survive in a recognizable shape for hundreds of years, for example when laid down in ritual language, the fabric of the story is likely to have been much altered by the process of transmission. To the Timorese mind, there was no term for 'myths', since 'myths' were considered to be the truth, the equivalent of history. In human society, myths incorporate memories of the past,

33 VOC 1226 (1658), f. 509b. The incident will be more fully discussed below. 
the experience of the present and the expectations for the future, all at the same time. In a traditional society, the future will then usually mean a return to a conceived past (Locher 1978:83). What is important to consider, therefore, is the function of the Sonbai dynastic myth as a charter of legitimacy. The elements of the narrative explain the origins of various Atoni groups, their early migrations and their relations with each other. They also explain the reasons why the Sonbai dynasty continued to be held in awe and deference, and why their political authority lasted in various forms until the 1950s. The Sonbai dynasty is also seen as the originator of West Timorese forms of agriculture, and is considered the source of the later division of power and authority among the Atoni. Finally, it is the possessor of supernatural powers that have far-reaching consequences.

There are interesting variations in the episodes preserved in various accounts of the nineteenth and twentieth centuries. While the Sonbai genealogy recounted above talks of five generations before the coming of the Westerners, several sources assign their exploits to just one or two generations. ${ }^{34}$ This is indicative of the atemporal sense of the past often found in non-literate cultures. The Sonbai lord could be one or many in the stories; there are also important variations in tone. All versions do agree that a Sonbai ancestor married the daughter of the Kune lord and took over his chiefdom in the central parts of West Timor; however, the two oldest accounts, by Müller (1829) and Heijmering (1847), disagree over whether it was a peaceful process. Müller claims that Kune was subjugated by brute force, while Heijmering roughly agrees with Fobia's version recounted above (Müller 1857, II:150; Heijmering 1847:17-27). Interestingly, the story here serves as the rationale for the peculiar position of the Kune family until the twentieth century. As the original lord of the land (pah tuaf), the chief of the Kune clan received a small part of the harvest from the lord of Sonbai or his regents until comparatively

\footnotetext{
34 I understand from Father Gregor Neonbasu of Kupang that there is a longer Sonbai pedigree collected by Father Eric Breunig, which is different from Fobia's account (compare Parera 1994:196). Parera, who originally wrote his text in 1971, collected folk stories from Mollo, which provided a list of Sonbai rulers that corresponds to that of Fobia (Parera 1994:268). Spillett 1999:115 also gathered the same list from an old ex-raja of Miomaffo. Johannes Cornelis Banu, the mafefa of Amfoan (interview, 13-6-2006), gave me another list, which contained largely the same names as Fobia's manuscript, though in a partly different order. In sum, it is hazardous to draw any conclusions about historical developments before 1650 based on the orally transmitted genealogies.
} 
recent times. ${ }^{35}$ His ritual role is illustrated by the important leu, 'sacred heirlooms', which were preserved in Miomaffo, the north-eastern part of the old Sonbai realm. The heirlooms were known as Nai Massu (Lord Smoke) and represented the original lineage of the lord of the land, Kune (Van Geuns 1927:466-7).

Maintaining the line of original owners of the land at the side of the current ruling dynasty is a well-known phenomenon in communities of the eastern archipelago. It is a part of the 'stranger king' syndrome which is so common in Austronesian societies, and which posits a ritual opposition between 'insider' and 'outsider' in a given polity. The Sonbai lord is a stranger king, and his position as an outsider is an important part of his position in the system. The pattern of the 'stranger king' myths is often similar: an ancestral dynastic figure arrives, subdues the original lord in a contest or by other means (in this case, a marriage), is elevated to princely status, and arranges a division of the realm whereby the original inhabitants or chiefs retain particular rights with regard to the land. Moreover, Kune adopts the role of providing wives for the lords of Sonbai, Kono and Oematan, which puts him in a ceremonial position of precedence, in spite of his loss of executive powers (Fox 2006:2, 6, 8-10). There are obvious parallels here with the coming of the Dutch and the Portuguese to Timor. In both cases they were voluntarily received by local rulers (Kupang, Ambeno), who were the original lords of the land and who were henceforth maintained and, in part, honoured by the foreigners.

A peculiar problem in this context is the geographical term 'Servião', which is associated by the Portuguese sources with Sonbai. The first explicit mention of this connection, to my knowledge, is a letter from the first regular Portuguese governor in 1703 that characterizes the Kono lord as 'the one who governs the Empire of Seruião for the aforementioned Sonouay [Sonbai]' (Matos 1974a:336). As we have seen, the geographical term Servião as such is mentioned in Godinho de Eredia's description from circa 1600, and also occurs on two maps that he drew in 1613. It is later mentioned by Dominican sources in the context of

35 The theme of an original lord of the land is common in Timor and on surrounding islands. Another example is the Nubatonis clan in Amanuban, which was superseded by the Nuban or Nope family (McWilliams 2002:62-3; Müller 1857, II:214-5). 
the events of 1641-1642. ${ }^{36}$ The Portuguese officer Francisco Carneiro de Siqueira in 1647 mentioned Servião as the 'centre of the island of Timor', a place where copper could supposedly be found. ${ }^{37}$ Certain modern traditions actually describe Sorbian as an ancient realm, associated with the Kune family, which encompassed Timor and the surrounding islands. ${ }^{38}$ The name occurs in numerous Dutch sources as Serviaen, Zerviaen and, later on, Sorbian. The problem is that this term in the nineteenth century alluded to a mountainous area of limited political importance in the north of West Timor, which more or less overlapped with the princedom of Amfoan. This ambiguity is partly explained by looking at certain late-seventeenth-century VOC documents, which make it clear that the groups that originated from the lands of Sorbian, namely the Amfoan and Taebenu, were also considered to be included in the larger Sonbai group. ${ }^{39}$ All this, of course, adds colour to the traditional narrative referred to above, which posits an original affinity between Sonbai and Amfoan. The earliest traceable history of Sonbai will be returned to in the next chapter.

\section{THE ELUSIVE EASTERN LIURAI}

While the identity of the central and western liurai, of Wehali and Sonbai respectively, is reasonably clear, there is considerable doubt about the liurai of the eastern component. The tripartition appears to have been more symbolic than real, and the details of the components changes with the circumstances. Several oral versions point out the lord of Likusaen as the liurai established in the territory of present Timor Leste, whose ancestral figure was the youngest brother of the Wehali and Sonbai ancestors. The name corresponds to Liquiçá, a reino to the west of Dili, which is mentioned from time to time in both Portuguese and Dutch documents. It enjoyed a certain local importance, but with

\footnotetext{
$3^{6}$ Durand 2006a:76, 78, 80; Santa Catharina 1866:300. A letter by the 'apostle' of Timor, António de São Jacinto, in Vasconcelos 1929:78-9, mentions 'the kings of Sertão' (probably a slight misspelling of Servião) who rejected the name 'Portugal' because of the fall of Malacca. To the missionaries of the 1640 s, Servião therefore appears to have been a comprehensive geographical concept including several kings.

37 Fiedler n.y.: 15, H 475b, KITLV.

$3^{8}$ Interview, Johannes Cornelis Banu, Kupang, 5-2-2005 and 7-2-2005.

39 VOC 1577 (1696), Dagregister, sub 2 and 3-1-1696.
} 
the exception of Pigafetta's account from 1522, there is nothing to suggest that it held authority over a wide area, let alone a major part of East Timor. Moreover, there are other candidates, for example, the double kingdom of Suai-Camenaça in the south-west of present Timor Leste, which is intermittently mentioned as the principal eastern realm in nineteenth- and twentieth-century accounts. ${ }^{40} \mathrm{~A}$ third candidate is Luca, a Tetun domain on the south-eastern coast, which is mentioned as a paramount power in the east, by Müller (1829) among others. ${ }^{41}$ Some accounts emphasize that Luca was not a legitimate power, but had usurped power in the east at an unspecified time. All in all, we are left with a highly confusing picture.

This ambiguity is already apparent in the oldest documents that treat the issue. There is a letter from a Portuguese governor, written in 1734, which alludes to a revivalist and anti-European movement in the period 1725-1728, long after the introduction of Portuguese authority. This revival included 'the idea of expelling [the whites] and the enthronement of their three kings Sonobay [Sonbai], Liquiçá [Likusaen] and Veale [Wehali]' (Castro 1867:243). The insurgents were never able to carry out their aim, but nevertheless, it demonstrates that the tripartition found in certain twentieth-century oral stories is not a new concept, if not as a political reality, then at least as a commonly held idea. However, there is another version of the movement, found in the 1811 Instrucções do Conde de Sarzedas, and evidently based on other eighteenth-century documents. This text cites Camenaça rather than Likusaen as the third component (Castro 1867:205).

Oral narratives picked up in the late twentieth century further elucidated the issue. A Tocodede-speaking adat elder interviewed in 1994 in Ulumera, close to Dili, emphasized the role of Wewiku-Wehali as the demographic source of the Liquiçá area. At the same time, the modern place called Liquiçá was not completely identical with the historical region of Likusaen:

$4^{\circ} \quad$ There is a slight ethnic difference between the Tetun-speaking Suai-Camenaça and the Tocodedespeaking Liquiçá (compare Bastian 1885:14), although Tetun and Tocodede are related Austronesian languages.

$4^{1} \quad$ Francis 1838:393; Müller 1857, II:91. The map at the back of Müller 1857, II, appears to show Luca as a princedom covering East Timor up to the borders of Wewiku-Wehali. This is clearly a gross exaggeration from any point of view. 


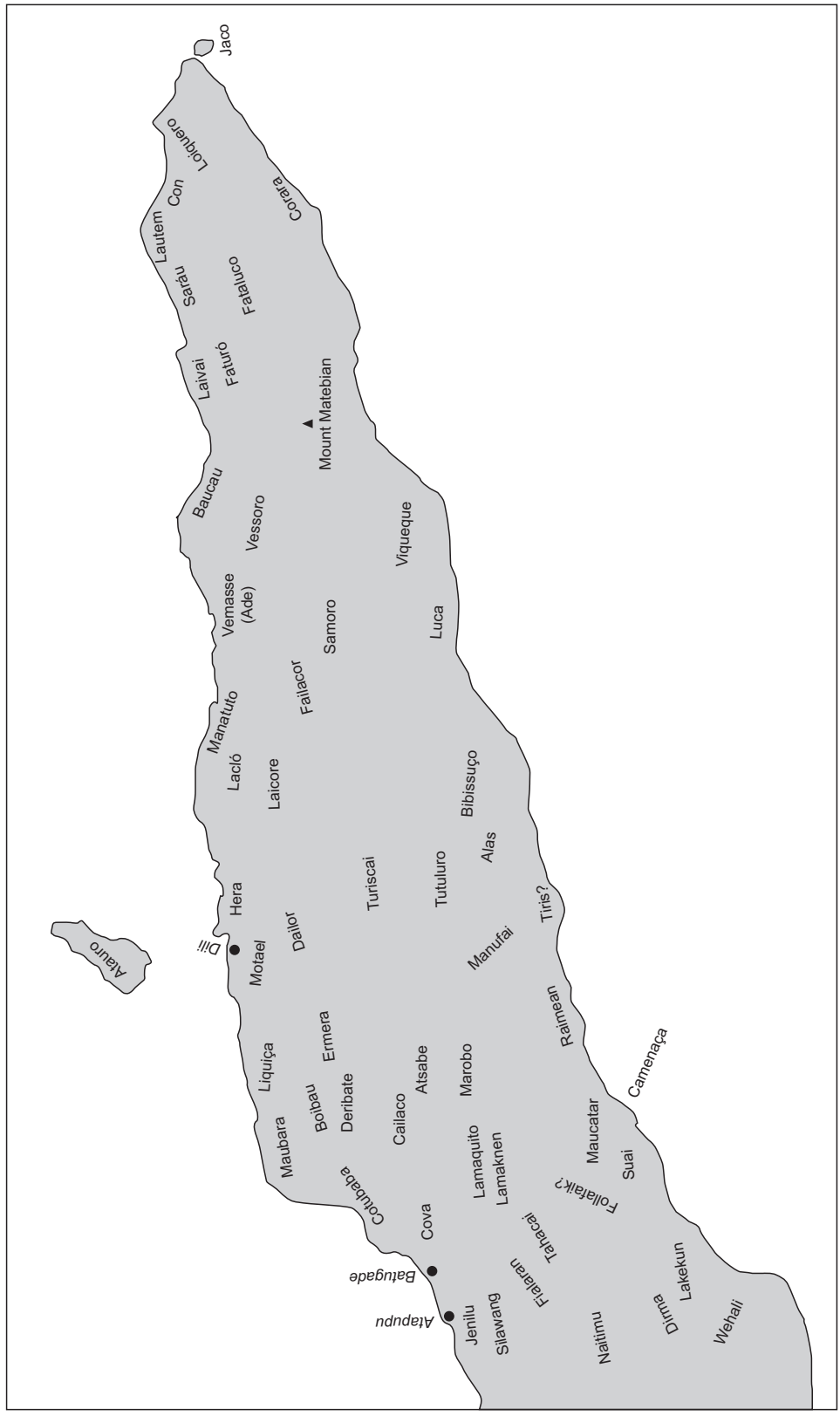

East Timorese domains 
Likusaen was not a kingdom but the name of a region. Mota Ain [Motael] was the centre of the kingdom, which consisted of Mota Ain, Tasitolu, Ulumera and Pissu. Likusaen means 'the limit or end of the journey'. [...] Mota Ain is made up of three kingdoms - Mota Ain (Amu); Loro Monu, which covers the area of Suai-Camenaça, and Loro Sae, which covers the area of Maunfahe [Manufai]-Same. All beneath the government of Mota Ain. Under the Portuguese, the liurai was called kornel. ${ }^{42}$

Another adat elder, in the kampung of Kaiteho, provided a similar story: 'The people here in Kaiteho came from there, Wehali, to Mota Ain, Dili, to Ulumera and then to Kaiteho. Mota Ain was the centre of Likusaen. Upeti [tribute] was given to Mota Ain by way of Ulumera and then to Kaiteho. The language spoken here is Tocodede. ${ }^{43}$

All this seems to imply that Likusaen was a comprehensive area in the west of present Timor Leste, the centre of which was Motael, situated next to present-day Dili. Indeed, Motael was a reino of considerable importance, which invited the Portuguese authorities to establish their new centre in Dili in 1769 (Matos 1974a:98-9). An encyclopedic entry from the late nineteenth century characterized it as 'the most important kingdom of the island in the Portuguese part'. ${ }^{44}$ Motael claimed to hold precedence over Suai-Camenaça and Manufai at the south coast, although the reality behind these claims is not apparent from the extant documents. However, if the entire area was included in one hierarchical system, it would explain the varying identity of the eastern liurai-ship Likusaen or Camenaça, depending on the relative strength or authority of either.

The occurrence of Luca as the paramount realm of East Timor in some nineteenth-century accounts is related to its position as a Tetun polity. While the demographic centre of the Tetun lies in Belu, in Central Timor, there is also an eastern Tetun-speaking area. This in turn is separated from Belu by an area inhabited by the Mambai-speaking people. The foremost reino of this eastern portion was Luca, which is

$4^{2}$ Spillett 1999:251, 253. I have changed the spelling of some names slightly, in order to keep the text standardized.

43 Spillett 1999:259. Slight changes have been made in the spelling of names. Peter Spillett interviewed persons connected with Suai-Camenaça in 1992, 1995 and 1998, but the narratives do not explicitly refer to Motael or Likusaen as central places (Spillett 1999:323-5).

44 The encyclopedic notes of Raphael das Dores, compiled in 1871-1892, are reprinted in Marcos 1995:33-66. For the reference to Motael (Montael), see pages 55-6. 
already known of in the sixteenth century. In 1647, the Portuguese officer Francisco Carneiro de Siqueira characterized it as the 'head' of the island at the eastern coast, and a place where the Portuguese unsuccessfully tried to prevent the Makassarese and Malays from trading. ${ }^{45}$ In 1661 it was characterized by a Jesuit writer as the best and healthiest place on Timor, inhabited by a good-natured population. ${ }^{46}$ According to interviews with the old titular liurai of Luca in 1994-1995, there was a historical connection between Wewiku and Luca, the kingdom of which was actually older than the maromak oan institution. Luca was supposed to have been a very large kingdom in early times, before the colonial dominance by the Portuguese monarchy. ${ }^{47}$ There were also smaller kingdoms in the region, which were branches of the larger kingdom, such as Takanar and Viqueque. The latter domain had a special connection with Wehali. The realm of Wehali in turn was defined by the liurai of Luca as including 'loro Sonbai, loro Wehali and loro Likusaen' - once again the old tripartite constellation known from stories found in other parts of Timor. ${ }^{48}$

Luca was the place of Uma Bot, 'the great house', which was the centre of the realm. Outside of Luca itself, however, were four minor kingdoms, namely those of loro Ossu-Ossuroa, loro Vessoro, loro Vemasse, and loro Waibobo (Spillett 1999:300). Interestingly, this particular information is confirmed by early documents. As we will see, the position of Vemasse on the north coast was controversial in the seventeenth century, causing conflicting Makassarese, Portuguese and Dutch claims. The VOC argued in a document from 1668 that Portugal had no historical rights to the coastal princedoms of Manatuto and Ade (Vemasse). In previous times they had been tributaries of the Kingdom of Luca, although they had abrogated this relationship some years previously. ${ }^{49}$ The Dutch claimed that the tributaries encompassed a rather wide territory in eastern Timor Leste, including areas where Austronesian languages like Galoli, and Papuan ones like Macassai, are spoken. Although this hier-

\footnotetext{
45 Fiedler n.y::13, H 475b, KITLV.

$4^{6} \quad$ Jacobs 1988:169. The praise is partly due to it being open to Catholicism.

47 Marques Soares 2003:45 claims that Luca encompassed a vast area in the east of the island. The border ran via Ue-Hedan, Rantau by way of Mount Lihu-Wani, Laclubar, Cai-Mauc, Aituto, Mount Ramelau and Suai.

$4^{8} \quad$ Spillett 1999:301. According to another interview, with a grandee from Wehali, Likusaen had authority throughout eastern Timor; Viqueque in particular was pointed out as being under the authority of Likusaen (Spillett 1999:158).

49 VOC 2285 (1733), f. 179-80; Hägerdal 2007b:557.
} 
archy may have been more symbolic or ritual than executive, it explains why Luca was accorded such high consideration in certain European texts. Once again, however, it must be emphasized that the eastern domains were considerably smaller than those in the west. In spite of the theoretical partition into three Timorese liurai under the maromak oan, the eastern component(s) did not have prerogatives comparable to those of Wehali and Sonbai.

On the preceding pages we have traced the pre-modern Timorese perspectives of political power. Obviously, the late date of the indigenous Timorese accounts complicates such an investigation, but nevertheless, it will constitute a necessary backdrop to the analysis of contemporary data from Dutch and Portuguese sources. We may therefore return to the chronology approximately where we left it, circa 1640, in order to trace the earliest colonial establishment on the island. 